\title{
Are EU business associations governable?
}

\author{
GREENWOOD, J., WEBSTER, R.
}

2000 


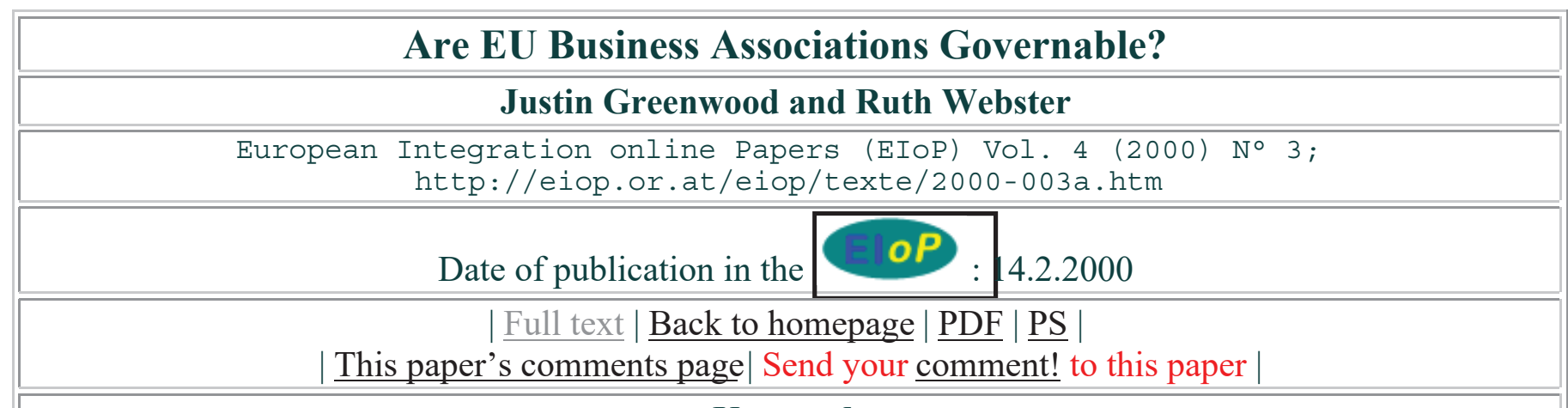

\section{Keywords}

governance, interest intermediation, interest representation, lobbying, pluralism, corporatism, integration theory, political science

\section{Abstract}

Business Interest Associations vary widely in their governability - defined as their ability to unify members' interests and ensure goal compliance. How can these variations be explained? To what extent is associational 'effectiveness' governed by factors in the external environment of an association and of its members, and to what extent can improvement programmes undertaken by associations themselves make a difference? Drawing upon interviews undertaken with 50 EU business associations in the autumn of 1998 and ongoing subsequent member interviews, analysis enables researchers to ascertain the conditions under which associations are likely to be in a position to contribute to the process of European integration. Comprehensive directory research is also used to settle a long-standing dispute about the number of 'Euro groups'.

\section{Kurzfassung}

Interessenverbände der Wirtschaft variieren erheblich in ihrer "Regierbarkeit". Regierbarkeit wird dabei definiert als ihre Fähigkeit, die Mitgliederinteressen zu vereinheitlichen und die Übereinstimmung von Zielen sicherzustellen. Wie können diese Divergenzen erklärt werden? Inwieweit ist die "Effektivität" eines Verbandes von Faktoren im externen Umfeld des Verbandes bzw. seiner Mitglieder abhängig, und inwieweit können Verbesserungsprogramme, die durch die Verbände selbst durchgeführt werden, zu Veränderungen führen? Auf der Basis von Interviews mit 50 EU-Wirtschaftsverbänden im Herbst 1998 sowie von laufenden Interviews mit Mitgliedern kann die vorliegende Analyse die Bedingungen erhellen, unter denen die Verbände in der Lage wären, zum Prozeß der europäischen Integration beizutragen. Ferner wird eine umfassende Untersuchung der Verbandsverzeichnisse zur Schlichtung des bereits lange fortdauernden Disputs hinsichtlich der Anzahl der "Euro-Verbände" genutzt.

\section{The author}

Justin Greenwood is Jean Monnet, and University, Professor of European Public Policy at the School of Public Administration and Law at Robert Gordon University, Aberdeen; email:

J.Greenwood@RGU.AC.UK; Ruth Webster is lecturer at the same institution; email:

R.Webster@RGU.AC.UK. 


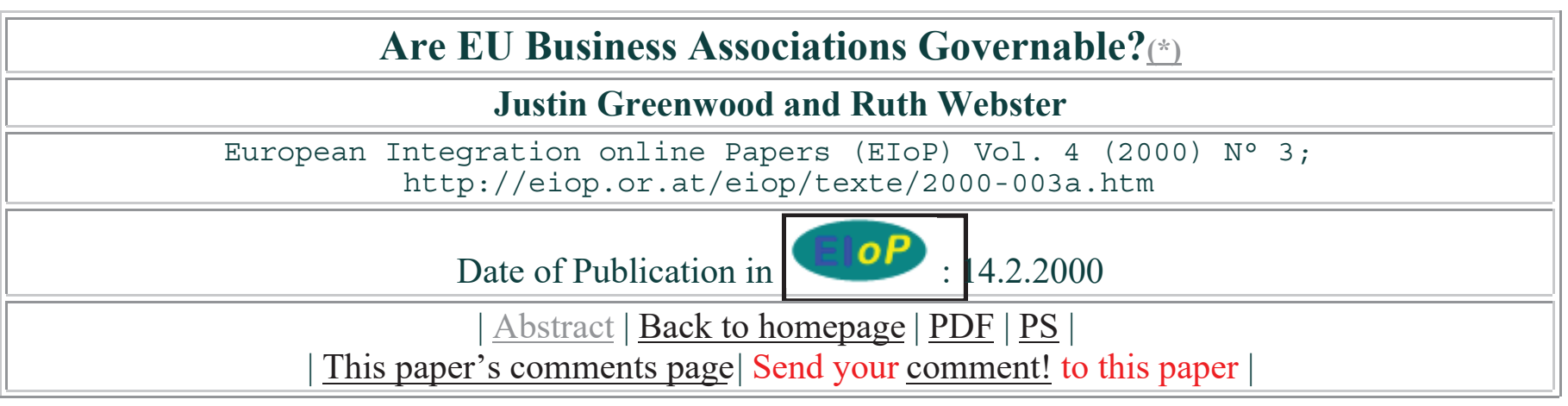

\section{Contents:}

- I. The Landscape of Business Interest Representation in the European Union

- II. What are the obstacles?

- III. Are there solutions?

- IV. Conclusion

- $\underline{\text { References }}$

All accounts of European integration acknowledge the importance of input by business interests to the everyday politics of the EU, and to some accounts the relationship between these and the European institutions are central mechanisms of integration. Whilst business input takes a variety of forms, ranging from action undertaken by individual (invariably, large) firms through to collective action outlets with varying degrees of formality, formal business associations retain their historic role as the largest, the most significant, and the most encompassing, 'sector' of business interest representation. The ability of such groups to be cohesive has frequently been questioned by both practitioners and analysts. These questions raise wider questions about accounts of European integration in which business interests are cast as central mechanisms. Industries that are 'economic giants but political dwarfs' as a result of the inability of their associations to go beyond lowest common denominator positions are familiar to many analysts. This is the key idea that 'organisation matters' in political significance, rather than simply economic muscle, and that interest organisation matters to the functioning of political systems. How does the relationship between interest associations and their members shape group outputs, how are associations conditioned by the political systems in which they participate, and to what extent can associations be improved through 'better management'? That is, what are the limitations of formal associations as collective actors of business in the $\mathrm{EU}$, and what are the prospects for such obstacles to be overcome?

\section{The Landscape of Business Interest Representation in the European Union ${ }^{\uparrow}$}

The number of formal business associations, other collectives of business, and firms which are politically active in engaging the EU institutions are notoriously difficult to estimate. Factors such as the variety of ways of accessing EU politics, the level of aggregation of business, the wishes of actors for visibility or relative anonymity, the diversity of territorial locations from which business actors engage in EU 'public affairs', organisational structures of firms and of their 'public affairs' capacities, make head counts a pastime of dubious utility. Yet despite such complexity no one seriously doubts the predominance of formal groups in business interest representation.

The most visible business actors whose purpose is primarily dedicated to addressing the EU level are formal EU level business associations (based in a variety of locations, though overwhelmingly in Brussels), and firms who have established 'government relations' offices in Belgium (invariably in or close to Brussels) and who have declared themselves by returning entries in EU related directory sources. A composite of 
seven recent Directory listings,(1) (including the European Commission database recently made available on the Web) suggests there are 914 formal business associations (of a total of 1,347 of EU level interest groups of all types) and 247 transnational firms with government relations offices in Belgium (339 in all EU locations). Corresponding figures for 1998, available for firms only, indicate around a 3\% growth in corporate (albeit self-selecting) listings in these directory sources over the past year. The relatively high degree of political activity by large firms in Brussels can be explained by a variety of factors, and which have been extensively reviewed elsewhere (Coen 1997; Green Cowles, 1995). However, not least among these factors are the difficulties which formal groups face as collective actors. Whilst the case study literature has identified individual business groups who are apparently influential partners in EU governance (see, for instance, Pedler and van Schendelen, 1994; Greenwood, 1995a), there are just as many cases, if not more, of groups representing otherwise significant industries with abiding collective action problems, and in particular which face 'lowest common denominator' type problems in platform building. Indeed, these terms have become somewhat hackneyed amongst the labels applied to EU trade associations. More specifically, to use terminology developed by Traxler (1991), EU business associations are often noted for problems of associability (the ability of an association to recruit members), and governability (the ability of an association to unify its members interests and to make them comply with its goals). What are the factors responsible for such problems, and what are the prospects for such groups to overcome them?

Deductive analysis is used alongside 'first snapshot' inductive evidence drawn from interviews with senior personnel in 50 Brussels based EU business associations undertaken in October and November 1998, and from a number of internal documents from associations and firms obtained by the author(2). These were supplemented with a small number of interviews undertaken with large firm and national association members of EU business associations, and with a selected number of interviews with senior figures in the Commission and Parliament. The interviews explored a series of issues around the ability of such associations, as product market actors (rather than as employers' associations, for whom a rather different set of issues apply - see Huemer, Mesch and Traxler, 1999), to work with their members to reach common policy positions and to act upon them. The sample was selected on a stratified basis, divided and sub divided by a range of criteria including sectoral characteristics and specificity, and whether members were firms, associations or a mixture of both types. This data has been used in conjunction with literature analysis in order to identify some of the variables to explain differences in the governability of EU business associations. To date, these centre on the characteristics of: the sector concerned, and it's external environment; the structure of members' activities and interests, and incentives upon particular actors to behave in particular ways; the representative organisation concerned, and its strategies; and the political environment in which associations operate.

\section{What are the obstacles?}

The single most important barrier to the development of cohesive EU business associations appears to be the lack of ability of the EU institutions to provide them with the type of institutional patronage needed for associational cohesiveness and high membership density. This lack of ability derives from a number of sources, but principally from the architecture of the EU, and in particular its lack of 'state like' properties with which to 'licence' monopolistic associations as governance partners. The role of the intergovernmental Council of Ministers at the head of EU decision making means that the supranational institutions of the EU, whose relationship with outside interests forms a crucial mechanism of integration, lack the ability to develop strength in their interlocutors. This position was most notably asserted by Streeck and Schmitter, who argued

'As long as the ...Parliament and the Commission...cannot autonomously determine the range of policy issues than come under its jurisdiction, its ability to influence the structure of organised group interests will remain low indeed' (1991, p.143) 
Thus, whilst there can be little doubting the emphasis placed in institutionalist based accounts of integration upon interest groups as the 'natural constituency of the Commission', the position of the Commission in multi level EU politics makes its ability to nurture corporatist type associations highly limited. Other factors limiting the institutional patronage of the EU include: the multiple layers and points of access to EU policy making; its sheer size \& complexity; and the fragmentation \& dispersal of the policy making process. These factors tend to create a 'lobbying free for all' rather than an organised system of interest intermediation. Whilst there are important qualifications, reviewed below, there is no sector where the relationship between business interests and the EU institutions are conducted wholly through an associational intermediary. There are, however, sectors where the discipline of members, and particularly national association members, in leaving contacts with the Commission to the EU level association is relatively high.

The multi level character of the EU can be held largely responsible for the schizophrenic nature of its economic management system. This swings between neo liberal agendas of deregulation, an ideology associated with a negative view of producer interest groups as part of the problem (rent seeking agents distorting efficient market allocations), and a more interventionist agenda where the EU seeks the help of organised interests to govern. In such a climate the contribution of associations is bound to be uneven. Where associations are institutionalised, so they tend to be powerful and attractive to their members to participate in. Whilst the rich case study literature on the subject carries examples of these, even the most institutionalised and likely cases, such as the pharmaceutical association EFPIA( $\underline{3})$ or the steel association EUROFER(4), exist alongside their members government relations offices (and well established networks linking these outside of the formal association) in Brussels. Indeed, even EFPIA, often held up as a shining example of a Euro group cohesive enough to deliver self regulation in lieu of public policy initiatives (Greenwood, 1995b), has recently undertaken fundamental internal restructuring in response to its Brussels based members by-passing it and going direct to the EU institutions. This is supportive of an important, but often overlooked, point dating from Coleman and Grant's (1988) work on the OBI project, that even the presence of private interest government arrangements do not necessarily mean that an association will be significantly less fragmented than others, and should not be automatically taken as an indicator of the governability of an association. Whilst the EC interest-institutional system was initially designed with the purpose of enabling corporatist structures to develop, such as institutionalised advisory committees, and policy decisions such as a refusal to talk to interests other than those aggregated in EU level associations, the wider architecture of the EU frustrated such intentions. Multinationals are able to exploit the multiple access point architecture of the EU without having to rely upon on collective action by virtue of their size. The relative ease of exit of members from their EU associations in favour of other channels of representation only undermines the associations. Where associations are left to be one voice amongst many, so the many will continue to use multiple points of access.

A further problem for business associations in the EU is an endemic tendency towards fragmentation, specialisation and diversity. This is a feature of business associability which has been well established in the extensive series of research projects arising from the Organisation of Business Interests (OBI) project in the 1980s led by Streeck and Schmitter (inter alia, Streeck and Schmitter, 1985; Hollingsworth and Lindberg, 1985; van Waarden, 1991; Lanzalaco, 1992). The OBI project examined the associability behaviour of 7 sectors in 9 countries, covering 290 associations, concluding that inherent weaknesses in the landscape of business associations have systematically undermined corporatist type governance systems (Traxler, 1991). The tendency towards fragmentation, specialisation and diversity is also well established in the collective action literature triggered by Olson $(1965 ; 1995)$. Olson's deductive analysis demonstrated how rational action would drive firms to member associations of a small size, where the benefits obtained from lobbying could be divided up between fewer beneficiaries, and where free riding could be more effectively controlled. Whilst there may be a sensible division of labour between business interests involved in segregated activities from the point of view of reaching meaningful common positions, the overall impact of specialisation can also be competitive. Frequent examples can be given, of which the first two represent (for business) a functional division of labour without competition arising, whilst the last four result in competitive interest representation. Thus, the oil industry has one organisation representing upstream producers, another for 
downstream producers, and another to provide the EU institutions with technical data affecting environmental issues. Similarly, tyre manufacturers have a technical organisation, and a more openly political trade association. On the other hand, glass manufacturers are specialised into flat glass, technical glass, insulation glass, textile glass fibres, and electronic glass fibres associations, and the outcome is overlapping specialisation from a core of common interests which results in competition. In some cases, the raison d'être of the EU business association is to represent the political interests of large firms in very specific market circumstances within the product chain. Thus, a branded names product association exists to enable consumer grocery manufacturers to represent their interests viz. large grocery retailers using purchasing power to exert market influence. These manufacturers are represented elsewhere in their own sector associations. Parcels operators also line up in specialist associations, in response to the stimuli of the single market - one group (US private sector) pro liberalisation, another (EU public monopolies) anti. Liberalisation of public sector monopoly sectors, classically, disintegrates the unity of homogenous business interest associations, as the structure of members interests changes, typically resulting in the development of specialist niche associations. Hence, a response to liberalisation of the electricity sector in Europe was the creation of specialist sectors representing electricity traders, municipal producers, and renewable energy, rather than the monolith international electricity association, UNIPEDE.

Another variation on the same theme is for a specialist trade associations to be 'front' organisations for a very small number of firms. These can take a variety of forms, but a well obscured type of control by firms is where identities are well hidden behind a national association basis of membership of the Euro group, but where one or two firms dominate the national associations. Thus, listings of associations of pickles, sauces, mayonnaise, or mustard manufacturers in directories at first sight conjure images of cute cottage industries speaking up for small time artisans, but in reality are dominated by a small number of multinational firm interests. Uncoincidentally, these associations operate from identical addresses, with identical constitutions, and annual general meetings held on the same date. In a variation on this, there are signs that national associations are now starting to 'rent' 'distant cousin' European associations as a spokesman on specialised issues, particularly where agreement in their own sector is blocked because of different national interests. Thus, for a relatively small fee, a UK drinks association has recently found that its membership of an EU leisure association is a good way of getting its views adopted under different cover by an association where there are no competing interests to contend with.

The author's primary data collection indicates that some of the most active multinational firms in European public affairs can hold as many as thirty different affiliations to EU business associations at any one time. In part, this reflects the multiple product interests of firms and the company culture for decentralisation or otherwise, but it also reflects what Coen (1998) terms their 'different bundle of preferences' for different issues, sometimes deliberately suppressing the interests of one segment of the corporate empire in favour of another, and the benefits to be achieved by working through multiple, specialised, channels of representation. By joining a number of small, specialised associations firms can access a wide range of benefits in exchange for a fee of relatively little consequence for it. They can take advantage of their size to poke their fingers in as many pies as necessary, although some of this activity seems self-perpetuating. Tetra Pak, stung by a major EC competition policy fine, has either created or joined four waste packaging associations with similar purposes (Butt-Philip and Porter, op. cit.). Some of these organisations have very specialised missions and a very small membership drawn from interests in particular market situations. ACE, the Associations for Cartons and the Environment, exists to represent the interests of paper board packaging interests drawn from within a highly fragmented paper industry with a history of difficulties in collective action, together with sack, and corrugated board manufacturers. This co-exists alongside other paper associations, and waste packaging associations or networks with environmental missions, and has a small number of mainstream members.

A further explanation for specialisation in business interest representation is also a consequence, as well as a cause, of the phenomenon. Where a number of organisations co-exist alongside one another, one strategy they use to differentiate themselves from eachother is to develop specialist 'issue niches' (Browne, 1990). 
Apart from avoiding treading on eachother's toes, these specialisms are also used as a marketing device to attract membership - on the grounds that organisations will develop reputations as the specialist organisation to join for potential members with particular types of issues. There is some evidence of this from the author's interviews with EU business associations, and, in turn, with their national association members viz. their own membership. Certainly, the sheer complexity of the EU means that a typical association might potentially have to monitor over 100 issues that could impact upon the interests of their members. Clearly, this is not possible for organisations that often have a low level of staffing (especially relative to many of their national association members), so organisations tend to pre select agendas so as to concentrate on a small number of specialised issues that they think will interest their members. Sometimes, this is in a deliberate attempt to interest their members. One national association in the construction sector, for instance, has decided to concentrate on 'social Europe' on the grounds that erecting the bogeyman of a higher wage bill might wake up an otherwise disinterested membership.

This tendency for specialisation in political associations amongst business can be contrasted with the demands of public institutions for fewer interlocutors, and more embracing associations, so as to simplify their interactive lives. Such a contrast is certainly not unique to the EU. In the UK, public institutions have called for a rationalisation system of no more than 60 'lead associations' to represent industry to government as part of an initiative to enhance trade association effectiveness. Yet, as Bennett has argued, such measures are likely to fail because of the incentives for business to specialise, and the failure of such measures to address these incentives (Bennett, 1997a). Ironically, the solution to 'cohesion' amongst business associations - specialisation and small size - can also be a source of weakness for them by undermining their utility to public institutions.

The tendency to specialise has been heightened by the increasing presence of large firms in Brussels as public affairs actors, which has in turn been a change agent for associations. Together with a host of other factors, such presence is in part cause and in part consequence of associational weakness and specialisation. In concentrated sectors, EU associations find themselves cheek by jowl in Brussels with the offices of their members. In some associations of firms, such as automobiles and petroleum, virtually every member company has their own Brussels public affairs office. Automobile companies even have their own network organisation, 'Brussels Automobile Representatives' (BAR), to link them, outside of their sector association, the European Automobile Manufacturers Association (ACEA). These relatively informal types of network structures have grown up alongside the presence of firms, and meet the needs of public affairs managers on outreach in Brussels to find regular meeting points for a variety of purposes. Sometimes, these develop into structures which can threaten the basis of the association; in banking, for instance, one player listed for the author thirty issue networks outside of the umbrella of the association, most of which were inspired by lobbying needs. The more responsive associations have sought to incorporate such networks by facilitating them - at one stage, the pharmaceutical trade association hosted a weekly 'Monday morning meeting' for proximate drug company government affairs officers. Once established, the Brussels public affairs offices of firms are bound to by pass the association by engaging in direct dialogue with the EU institutions, if only because of the need to justify their existence. To a certain extent, this happens with offices located in the member states. One example of this concerns a public affairs manager of a large firm whose remit covers Europe as well as domestic politics, when he told the author that he 'goes to Brussels to please the boss and to be able to say - that's Brussels done for a while'.

Following the example set by the European Chemicals Industry Council in 1991, most associations of national associations have responded to the increasing political activity of large firms in their sectors by admitting them into some category of membership, or, in some cases, transforming themselves to become solely direct firm membership organisations. The rationale for following the latter strategy has often been to speed up decision making (because they remove the need for their members to consult with a further tier of members), and in removing a tier of democracy to prevent policy positions from being too diluted - the 'lowest common denominator' problem. For some, the admission of large firms into membership has been a way to enhance the resources of the association, be they fiscal or through acquiring technical expertise with 
which to satisfy the needs of the EU institutions. For some, it has also been a way of coping with by pass realities as large firms engage in direct dialogue with the European institutions. Whilst the glue of many EU associations, particularly the less effective ones, can and has been the historic preferences of the European institutions for collective dialogue, in many other cases the practices of the institutions in engaging directly with large firms has undermined the association. Institutionalist accounts thus stress the positive and negative impact of institutions upon group development. In one internal strategy review document obtained by the author, a large multi sector EU association (of associations) recorded that

"It was noted with great concern that certain Commissioners and senior Commission officials of importance to (this organisation) have little or no regard for trade associations in any form (whether national or European) and turn to a selection of major companies directly for information and advice ... in view of the present negative attitude of some Commission personalities towards most trade associations, and the special position some major companies have won as advisers to the senior echelons of the Commission....."

Certainly, it is now something of an orthodoxy throughout the European institutions that trade association officials are 'industrial civil servants' who lack the technical expertise needed to inform policy formulation, and that trade associations produce lowest common denominator positions. But the problem is not just one of circularity - of institutions talking to firms because of trade association weakness which in turn makes associations weaker. The European institutions also undertake dialogue with large firms as a means to enhance their own legitimacy; and, to re-iterate a point made by Coen, as a channel of communication to national governments (Coen, 1998). Trade association officials complain that too many EU officials are charmed by the prospect of dialogue with household names. But they also complain that such dialogue is undertaken as a means of a 'divide and rule' strategy.

The classical trap of trade associations is to be caught between the public institutions they engage, and their own membership constituency. Public institutions can make excessive demands of them to deliver a high level of collective opinion when such agreement between member states would be near impossible. The need to maintain long term working relationships with the institutions means that associations need to compromise the undiluted interests of their members. In meeting the requirements of the institutions for associations to be two way channels of communication by explaining EU policies to their members, associations are often suspected by their members of 'going native'. Sometimes, this is not without justification; institutionalist accounts of collective action explain very well how actors can become socialised by the settings in which they participate, while rational choice theory predicts how organisations can have a quite different set of interests to those of its members. UNICE, for instance, the peak cross-sectoral Union of Industrial and Employers' Confederations of Europe, can enhance its own status by participating in institutionalised social partnership. In recognition of this, its members have kept the organisation on a tight rein to prevent any meaningful agreements from emerging from UNICE's dialogue with the trade unions. Associations can also fall victim to being the 'collective cloak' for members who might shy away from being associated individually with difficult and sometimes controversial public affairs issues. One experienced company government relations advisor told the author during interview that 'what you do is to give trade associations the crap'. Inevitably, this makes the maintenance of relationships with the institutions difficult for associations.

A further significant obstacle for associations is that they are not change oriented in the ways in which their firm members are. They usually lag behind changes which arise in their own sectors because they do not get market signals through everyday interactions in the same way as firms do, and because the need to be democratic means that many have to be bureaucratic by design. Olson (1995) points out that associations which are closest to their members are often the least change oriented, in that these tend to be small associations which are tightly controlled by, and therefore tied to, their members. Large cross sectoral associations, on the other hand, tend to be more change oriented because they are not obliged to defend to the death a particular sectional interest, such as a sector in industrial decline. 
A further set of reasons for stasis amongst EU business associations concerns the bounded rationality basis for membership, which fails to provide incentives for such associations to develop membership services. This is based on a comprehensive series of arguments, extensively rehearsed elsewhere, that collective action theories have often overestimated the risks of failure in organising collective interests, and that large firms remain happy to bear the costs for the pursuit of collective goods despite these being potentially free rideable. These ideas have been applied to the EU level by a collection of analyses in Greenwood and Aspinwall (1997). Membership of EU business associations is often either semi automatic, in that collective action 'problems' do not tend to arise among organisations which are already politically active, such as national association members of Euro groups.

Where membership is informed by assessment, whether by national associations or by firms, it tends to be more on the basis of the potential costs of non-membership than on the quantifiable benefits of membership.

Whilst some firms and associations will freely speak of membership decisions being on a 'value for money' cost-benefit basis, sustained investigation (reviewed in Greenwood, 2000) casts real doubt on these claims. One recent survey found that continued membership by national associations of corresponding Euro groups exists despite widespread lack of clarity among them about the benefits (Compass Partnership, 1997). Internal review documents from national associations are often full of criticism about the lack of benefit appraisal in their own affiliations to EU associations. It is not uncommon for government affairs departments of large firms with highly diverse activities to lose count of how many associations they are members of, and to be unable to cite the total costs of company affiliations. Similarly, there are cases known to the author of affiliation fees in excess of one million Euros to pass without periodic evaluation. A further sign of the lack of systematic appraisal comes with the lack of co-ordination of association membership within company family structures. Many subsidiaries are members of the same association as their parents. Whilst this may appear as a means to increase influence within the association, it is often more due to the lack of ability of firms to communicate within themselves. Some EU business associations find themselves the subject of questions from parent companies as to what position their subsidiaries are taking on a particular issue, or enquiries from subsidiaries about parents. Often, firms lack sufficient central information and decision making capacities to be able to exercise coherent - let alone rational - choices. Some firms have completely decentralised cultures and structures, such that a trade association membership may be the 'domain' of one part of the business, and centralised public affairs managers may be discouraged from involvement. Public affairs managers in company HQ may even be unaware that different parts of the business are taking opposite positions on a particular issue through different associations, or if they are aware find themselves unable to impose a single company position upon these different parts of the business.

These factors do not deny the presence of rationality in membership decisions. But it does cast doubt upon some of the more uncritical uses of economic accounts of political behaviour. An alternative approach is to emphasise how the 'cost of non membership' basis of affiliation tends to significantly bound the rationality. If members remain in EU associations principally on auto pilot, for the lack of good reasons to leave, or for reasons such as keeping associations away from potentially damaging positions, keeping an eye on competitors, for networking or 'club' or 'the thing to do' type reasons, they are unlikely to be exerting pressures to enhance the political effectiveness of their associations. If large firms or national associations do not rely on, or even require, their European associations to be their main strategy of political representation, so such associations are not subject to intense pressures for cohesiveness. This conclusion means that there is a lack of incentive for such associations to be change oriented in that there is a lack of drive from members. There is a lack of demand for, and thus supply of, selective economic incentives such as insurance policies or services, and in some cases even for information, which many members are well capable of undertaking for themselves. This is not to deny that such pressures are absent. Medium sized firms, small firm size sector national associations, or those from southern Europe, tend to have less options for political representation on resource grounds, join fewer associations, and therefore rely on the 
associations they do join for political action. EUROCHAMBRES, the European Association of Chambers of Commerce, is a good example where larger members use the organisation more for club or insurance policy type reasons, with less resource rich members using it more for political representation. Similarly, some EU associations report intense pressures upon them from the European institutions for collective viewpoints. Nonetheless, the pressures for cohesion do not tend to come from the largest members, while in the case of institutions there have been steadily decreasing expectations of what business associations are capable of. These may have reached such an extent that the main use of some business associations to the European institutions is to give advance warning of differences, and of potential trouble ahead in Council decision making. David White, Head of Regulatory Unit, DG III, reflected at a conference on trade associations that
"when we are looking at technical and legislative problems we are more interested in getting a rich position than in getting a unique position. I think we understand that a European trade association is representing a very wide range of different interests and they do not invariably speak with one voice and have a single view. Some opinions that we have received have worked on the lowest common denominator principle, so that by the time they reach us they are of precious little use; they do not say anything. It would be much better to say 'well some of our members think this and some think that', because this builds up the picture and helps us to understand what is going on" (Bennett, 1997b, p.10)

In practice, the position tends to be much more differentiated that the caricatures drawn here. Some sectors possess sufficient characteristics to be able to predict the presence of a cohesive association. A summary of these from the arguments presented so far, together with issues well established to date from the research literature (for a summary of these, see Bennett, 1997c), include:

- Global, European wide or national/local markets in which members are engaged, where predominantly global and local marketplace identities for a given sector may inhibit EU associational identity

- EU institutions which implement a policy of engaging only with associations and not with their members for collective issues affecting the sector

- The presence of a specific, historic and stable regulatory regime specific to the sector

- A stable sector. Sectors considerably subject to fluctuation are naturally reflected in changing associational membership.

- Company members which are of a similar size (Bennett, 1997c)

- Sufficient, but not over, concentration of the industry. Hence, Boléat (1996b) calculates the 'ideal size' to be around 70 company members. Excessive fragmentation of an industry, such as tourism, makes collective action extremely difficult, while excessive concentration may even undermine the reasons for a collective voice if firms are sufficiently few and large to undertake most of their public affairs needs themselves.

- A strong sectoral identity and a clear and unique position in the product chain. Associations easily able to put a boundary around the activities of their members tend to enjoy greater coherence, and those with a clearly defined position in the product chain find it easier to identify the interests of their members.

- Members with a similar profile of economic activities and interests. The greater the diversification, the more likely it is that members' interests will clash.

- A sector which is not divided by technology, with some maturity in the product cycle. Some sectors have been divided by competing technologies which has made it impossible to reach agreement on regulatory standards. Thus, the 'software patent' directive completely divided IT firms between those in favour of the copyright of a particular type of software, and those against, depending upon the type of operating systems on which their machinery depended (Coen, 1997)

- Market conditions which encourage firms to see risks and opportunities in the same way, such as declining profit margins, or over capacity (Bennett, 1997c);

- A regional (e.g. European) identity, where firms may have a 'European' position to adopt in world 
trade negotiations, such as the 'export' of technical standards for the global marketplace.

- The presence of a 'common enemy' which binds members together (thus, chlorine manufacturers work well collectively because all manufacturers face a current EU agenda geared at the phasing out of mercury as a component in the production of chlorine, and longer term threats to their interests posed by a range of environmental concerns)

- Where issues are sufficiently controversial for members to require a 'collective cloak', in which no single member wishes to 'put their head above the parapet'. Typically, these may involve labour market, environmental, or food safety type issues.

These 'luck of the draw' type issues are likely to considerably assist EU business associations in their search for cohesion. On the criteria identified above, the association most lacking in the features required for governability would be EuroCommerce, organising retail, wholesale and distribution issues in the EU, while the association with the most favourable conditions would be EuroChlor, the chlorine industry association. But beyond these environmental conditions, what deliberate actions can such associations take to enhance their governability?

\section{Are there solutions? ${ }^{\uparrow}$}

The obstacles reviewed above limit the 'solutions' to cohesiveness that are in the hands of associations themselves. The structure of incentives may solve micro level problems, but in doing so they contribute to the creation of wider ones. Thus, the traditional 'solution' to the lowest common denominator problem for business is to create small, specialised associations, which in turn makes dialogue for EU institutions difficult by increasing the number of associations it needs to engage. The task is therefore to change the incentives for business. If, for instance, the European institutions refused to engage with rival associations in the same sector, or even played off one set of interests against another, it would only be a matter of time before such associations merged. This is precisely what happened in biotechnology (Greenwood and Ronit, 1995), but the multiple access points to EU policy making, together with the lack of co-ordination capacities across the European institutions to do this means that such actions tend to be the exception rather than the rule. History suggests that a similar obstacle would undermine other ideas that have been floated, such as setting membership density targets for Euro groups before institutions engaged with them.

Nonetheless, the historic preference within the Commission, in particular, for encompassing European level associations does at least provide an incentive for associations to continue to embrace a diversity of interests. Whilst large firms may not rely upon sector wide associations for political action, they do at least participate in them, in part to please the European institutions. Sometimes, such associations have developed informal ways to resolve the diverging size of small and large firms within them, such as a greater degree of informal influence for large firms in return for providing a greater share of the resources (including time) needed to operate associations (van Waarden, 1991). Where associations have arrived at such compromises, so they can sometimes manage the tensions of differing interests within them to acceptable levels. There is also evidence from the OBI project that higher participation rates from large firms can positively influence the density of associations, and participation by such firms from the early stages of an association can improve the decisiveness and effectiveness of its political activities (ibid.). Impressionistic evidence from the author's interviews with 50 associations is supportive of these observations. Nevertheless, informal settlements can be fragile, and it is often only a matter of time before deep-seated conflicts between different types of interests present within the association surface again. These prevent the association from arriving at meaningful common positions, or agreement on the range of activities undertaken. The desire for encompassing associations within the European institutions may even sustain a patchwork of overlapping associations. This is because large firms are encouraged to play 'happy families' with their smaller brethren in the formal sector wide association, yet find them so cumbersome for political action that they use their own alternative, exclusive, collective 'rich firm club' structures for political representation. Different associations within the same sector can thus be sustained, one fulfilling demands for encompassingness, 
while the other is better geared to 'lobbying'.

Where the institutions may potentially have the power to undertake policy initiatives to enhance the status of associations, and which are not disabled by the lack of co-ordination capacities, the current agendas of EU politics continue to tie their hands. For instance, the recent climate of 'openness and transparency', and the agendas which have informed it, have lead the EU institutions away from any concept of 'recognition' of producer interest groups, on the grounds that to do so may privilege the already privileged at the expense of latent groups or underdeveloped domains, and in particular those representing citizen interests. The very concept of a 'level playing field', promoted by a series of EU policy initiatives, is indicative of an agenda which is wary of the potentially dominating power of trade associations. This agenda has been strengthened by the enhanced role of the European Parliament in EU politics. Indeed, the increasing power obtained by the European Parliament since the policy of 'dialogue with Euro groups only' was in place only multiplies the problem of providing the institutional patronage necessary for interest associations to flourish, because it nourishes multiple access points for outside interests. Multiple access points deeply structure the dynamics of collective action, and only enhances the lack of dependence by large firms upon interest associations for political representation, which in turn will continue the lack of internal pressure within groups for reform. If institutional patronage is the answer to 'cohesive' Euro groups, then the EU does not possess the architectural properties required to provide it.

This is not to belittle the contribution which factors such as leadership and management might make to collective life. The most experienced General Secretaries have developed a 'nose' for judging those policy circumstances where there are reasonable prospects for collective action, and to avoid issues where the interests of members may be so opposed (such as state aids, tax harmonisation, and product liability) that common platform seeking is futile. Indeed, finding a 'common enemy' as the basis to launch an association has proved the basis of success for some organisations. ACE, an issue alliance dominated by Tetra Pak to respond to a 'dioxins leaking into milk cartons' 'scare', found its 'success' in combating the issue the basis for the establishment of a formal association. Despite the fact that the original issue had gone away, the organisation, flushed with a reputation for success, simply found other things to do. Ten years on from its conception, the association retains all of its original members and enjoys a $100 \%$ membership density.

The position of General Secretary in such a diverse interest environment is essentially one of risk manager, demanding a unique combination of management and political craft. The relatively high turnover of General Secretaries bears witness to the tightrope many walk between the political sensitivities of their members, and with other potential membership constituencies. Some practitioners see this as evidence of lack of quality amongst EU trade association personnel (Boléat, 1996a), although there may be a wider tendency amongst them to see the failures of associations as issues of management and communication (see, for one example, Redpath, 1996), rather than as structural features of the environment in which they operate. Whilst many General Secretaries have ambitious change oriented agendas, disagreement between members means that the status quo often prevails, which may also be a sub optimal outcome for members and the basis for dissatisfaction, and ultimately the basis for a grievance against the postholder. The most enterprising General Secretaries have often fallen victim to these forces, or to historic disputes which have been exacerbated by personality clashes. Some have responded to the straightjackets imposed by their members by taking risks in implementing change agendas in the hope or receiving subsequent support from the majority of members. One highly regarded General Secretary lost his position after promoting his industry on a trade mission to China because members had not been consulted over the visit. Another lost his post through his attempts to broaden the basis of association membership beyond that of domination by two large firms.

Most frequently, the bitterest disputes with EU trade associations have been caused by attempts by the General Secretary to change the basis of the association from one that is exclusively comprised of national associations, to include firms. One known to the author is forbidden to communicate with large firms other than through his members. Yet, as was argued earlier, this type of debate is an inevitable response 
associations face to pressures in their external environment. The incorporation of large firms within UNICE as 'advisors' came after a long campaign in which firms had acted as an outside pressure group (in the shape of the European Enterprise Group) for the reform of UNICE, following its failure to pick up on key issues affecting employer interests. Yet even then the settlement came with a series of strings attached, notably that firms would have no voting rights within UNICE, and that their financial contribution would be limited to a maximum $25 \%$ of resources. The presence of the 25 or so firms in the UNICE 'Users Advisory and Support Group' bears testimony to the leadership skills and courage of past General Secretary Zygmunt Tyszkiewicz, but almost a decade after its inauguration its role remains controversial within UNICE, and has not advanced beyond the original role sketched for it. Today, there remains no cross-sectoral business organisation dedicated to representing the operational, day to day lobbying, needs of large European firms for political representation.

The most mature EU business associations seem to be those which have gone beyond these debates to link the encompassingness of national associations with the political strength and lighter consultation requirements of large firms, and which have settled debates on constitutional voting rights. Most associations do not vote or do so only in the most extreme conditions, but prefer to arrive at policy positions by consensus, or to reflect the informal settlement of influence between large and small firms described earlier. Nonetheless, some have found the discipline of having qualified majority voting (QMV) present in the statutes to be a helpful device in forcing member compromises. In some cases, these QMV rules have followed the precise allocation of votes in the Council of Ministers. Mature associations also seem to be those that have devolved considerable power to the secretariat to act and pursue long term strategies, despite the short-term constraints, fluctuations, and pressures of their members. This scenario seems to be the exception rather than the rule in European business associations, not least among smaller, direct membership associations, which are sometimes tightly controlled by their large firm members. The idea of members maintaining affiliations by a desire to prevent an association from being politically active, either per se or on a particular issue, is by now so well recognised that the practice has lent itself to the phrase 'the avoidance of collective bads' (despite its more recent popularity, a term first coined by Hardin in 1982) (van Waarden, 1992). As with the earlier example of UNICE's participation in the social dialogue, members have often deliberately kept their organisation on short leads to prevent their organisation from developing policy areas too far, or from 'going native'. Yet such short leashes prevent secretariats from developing working relationships with the European institutions. One Commission official tells a story of a General Secretary turning up to a consultative meeting to announce that there was nothing he could react to in the course of the discussion of a meeting because his members had instructed him not to co-operate on the issue under any circumstances (White, 1997).

McCann, drawing on earlier work by Pestoff, and Cawson, identifies two key indicators of association maturity and of depth in association-member relations. The first of these is the ability of associations to go beyond the aggregate preferences of their members and become actors in their own right, rather than communication channels between business and the state. A second is the ability to define and redefine interests, i.e. to influence and even change their members perceptions on what their interests are (McCann, 1995). This is one of the roles for associations desired throughout the European institutions, and an idea present in early integration theory. That is, a Commission starved of democratic contact and legitimacy would invest in European level associations in which their participants would increasingly come to recognise, and identify with, European solutions, and become the agents for the transmission of such ideas in domestic politics. Such an idea is supportable more by deductive analysis than empirical evidence. However, there is clear evidence from the author's interviews of large firm members in a number of sectors who have rationalised on membership fees by letting their affiliations to some national associations lapse, and concentrating membership in European level associations. At a more operational level, the European institutions want associations to be a bridge to explain EU level policies to their members, and this is undoubtedly a role which most associations have undertaken, to varying degrees of effect. Indeed, there can be little doubt that associations have played a role in the political education of their members about the EU, and most certainly in the dissemination of information about EU public policies, a role that even the most 
problem Euro group can perform.

Commenting on his wide experiences as a practitioner of associations per se, Boléat remarks that 'all have rather cumbersome governance systems, and they all have to devote significant resources to reconciling the interests of different groups of members (Boléat, 1996b, p.10). At the EU level, a good deal of thought has been devoted within association management circles to organisational designs which enhance the capacity for speedy decision making without sacrificing democracy, although there are clear limits to the extent to which structural and political problems can be 'managed' away. There remain, however, associations with seven tiers of committee decision making before it is able to pronounce an official position, and General Secretaries who defend such practices on the grounds of enhancing technical input. Inevitably, these are the associations who struggle to meet the consultative deadlines imposed by the EU institutions. One EU official tells of receiving 'the most beautifully set out, thoroughly argued assessment of a Commission proposal which had been adopted six months earlier' (White, 1997, p. 74/5).

There is considerable interest in association circles in 'flat' decision making structures, and in particular those which are geared at responding to issues rather than having a regular cycle and tiers of committee meetings. At least one organisation has combined this with strategies designed to maximise the participation of their members. Thus, a member is asked to perform the role of 'issue champion,' and to take responsibility for developing the association's response on that particular issue. A firm, for instance, will be asked to use its resources to negotiate informally with other members behind the scene, and to come back to the association to propose a formal position. By the time the draft is presented, all the substantive discussions are over, and it therefore takes the association just one meeting to come up with a common position. Another association has taken to assembling 'quick response teams' for particular issues that last just as long as are required. A number of these ideas seemed to have been inspired by examples set by the largest EU trade association, CEFIC, as well as by a more strategic level player, the European Round Table of Industrialists (ERT), which operates more as a 'think tank' than a lobbying organisation. Certainly, the sheer size of the CEFIC 'family of associations' enables its influence to be felt far beyond its own immediate circle, while ERT has provided a model to some of how to achieve company participation at the highest level.

In addition to streamlining decision making, these examples are aimed at addressing another core problem faced by EU business associations - membership participation. Several organisations claimed to have deliberately kept their secretariat small as a means of involving their members. Where, for instance, members are delegated responsibility for creating drafts of position papers, so the legitimacy of these positions tend to be greater than if a secretariat not directly involved in industrial affairs had drafted them. One association reported participation problems so chronic that they had to fill up the time allocated for an annual general meeting with a two-hour coffee break. Others have learnt to build in social time to the AGM on the grounds that difficult decisions are easier to make if members get to know one another, although there are complaints from members about 'tourism AGMs' in inconvenient destinations. Other ideas include the use of 'three strikes and you're out' attendance rules, and the development of intranet technology.

Other self-development ideas have been drawn straight from management manuals, and have often been applied by General Secretaries with an 'industry' rather than a public affairs background. They include the use of business plans, Management by Objectives (MbO), the use of performance indicators, outsourcing (particularly of non core services such as translation), developing the forward and strategic thinking capacity of the organisation, and even time cost accounting of staff set against strategic objectives. Where these ideas have been sensitively applied to organisations with a democratic mission, some valuable outputs are demonstrable. But there are still 'blind spots'. Few organisations have a General Secretary on performance related pay, or on freelance type contracts. While 'pinpointing the credit' for public policy outcomes is not possible, and may be culturally unacceptable in European public affairs or simply seen as unwise boasting, associations come from a business world where there is much experience of relating performance to objectives, and where assessment can be undertaken on a confidential, but accountable, basis. Another 
common weakness is the absence of imaginative staff development strategies, such as secondments to avoid 'path dependency' where actors go on using a solution to their problems even after it ceases to be useful, because such solutions are the limit of their knowledge. To some of the smaller associations, such a possibility would be a luxury. Some of these have become very dependent upon just one person, and it is difficult to see the association surviving beyond a retiral. One solution some have tried to this, and other, problems has been to maintain a presence by hiring an association management company. There has been steady, rather than spectacular, growth in this sector in recent years, led by players such as Ernst and Young (E\&Y Association Management), GIC, the European Consulting Company, and Devries. These enable a Brussels presence without having to resource a dedicated office, and extend beyond simple consultancy to the entire range of functions involved in managing a member organisation. They have proved popular with American firms and those on a low resource base, and appear to be growing at a steady (rather than spectacular) rate. They do enable otherwise stranded organisations to access expertise very quickly, and provide a solution to circumstances where members find it difficult to communicate with one another because of commercial pressures, but easier to let an independent know just how important an issue is to them.

Beyond management technique, however, there is little better for an association to do than to position itself as part of the solution rather than part of the problem. This would include the familiar idea of making an association indispensable to resource starved EU institutions, particularly as most associations have more staff than a corresponding unit in the Commission. Those which can provide a high level of technical expertise, or the ability to deliver self-regulation in lieu of directives, often find themselves dealt a winning hand. Amongst the former, the petroleum industry stands out by having an apparently separate organisation to provide technical information on key environmental issues which have informed the Auto Oil programme, and may well help explain how the outputs from phase 1 of that programme favoured the petroleum industry over can manufacturers. Tyre manufacturers have used a similar device, using self-regulation based on time delays for testing and introducing new products as a basis to prevent car manufacturers from using their power to pressurise individual tyre producers into diversifying tyre standards. The need for tyre and rim manufacturers to present a united European front in world trade negotiations has also exerted a discipline for collective solutions. The cement association CEMBUREAU also has a reputation for influencing policy through monopolistic control of technical information. Amongst organisations delivering public policy through self-regulation, advertisers stand out, and indeed this industry was specifically called upon to deliver self-regulation within a two-year period by the Distance Selling Directive. Despite the advertising industry being highly fragmented, it has been able to successfully deliver what has been required of it, and in doing so has been able to retain control over its domain.

\section{Conclusion}

The lack of governability of a sufficiently large number of EU trade associations presents serious questions for accounts of the integration process that place significant emphasis upon their relationship with the European institutions to explain the development of the EU. It also questions the ability of associations to be routine governance partners with the institutions. Business incentives to undertake collective action in small and highly specialised associations provide for fragmentation in the overall landscape of business interest representation, and do not match the aspirations of the EU institutions for single structure dialogue partners. Nonetheless, where associations are small and specialised enough to be cohesive, and at the same time broad enough to satisfy the needs of the EU institutions for a particular issue, they can offer reasonable returns to the institutions as a governance partner on an issue basis. These hardly amount to even the 'islands of (sectoral) corporatism' conceded by Traxler and Schmitter (1994) in revising Streeck and Schmitter's 'pluralism in the EU interest environment' caricature of 1991.

The EU does not possess the properties to be able to provide the kind of institutional patronage in which stable associational governance can flourish. The presence of multiple access points to EU public policy 
making, in particular, have developed a diverse landscape of business interest representation outside of associational contexts. A key part of this landscape includes large firms and the networks established between these, for whom multiple access points have reduced the need by large firms to use formal associations for political representation. In this account, the institutional architecture of the EU limits, rather than nourishes, the contribution by business interest groups to governance. These limitations, in turn, place boundaries on the extent to which such associations can benefit as political actors from self-improvement programmes.

Whilst there is a lack of internal pressure for reform within EU trade associations, a number have taken the initiative to draw from a range of ideas to maximise their governability, and the most mature associations have developed the ability to construct and change member perceptions of interests. Most self-development programmes, whilst geared in the main to enhancing the relationship between associations and their members, and to maximising the utility of associations to the EU institutions, have 'glass ceilings'. Provided associations learn to maximise their potential, and learn to live with being just one among a number of channels of political communication for business interests, their future role in EU governance seems assured. Organisation, as the slogan goes, matters, but not as much as the organisations - whether associations or institutions - involved would wish it to.

\section{References $^{\uparrow}$}

Bennett, R J (1997a) 'The Relation Between Government and Business Associations in Britain: An Evaluation of Recent Developments', Policy Studies, 18, 1, pp 5-33

Bennett, R J (1997b) 'Trade associations in Britain and Germany compared', in Bennett, R (ed.) Trade Associations in Britain and Germany, London, Anglo-German Foundation, pp 12-22

Bennett, R J (1997c) 'The Impact of European Economic Integration on Business Associations: The UK Case', West European Politics, 20, 3, pp 61-90

Boléat, M (1996a) Trade Association Strategy and Management, London, Association of British Insurers $(\mathrm{ABI})$

Boléat, M (1996b) ‘Benchmarking Trade Associations', Association Executive, Autumn, pp 10-11

Butt-Philip, A and Gray, O (1996) Directory of Pressure Groups in the EU, Harlaw, Cartermill

Butt-Philip, A and Porter, M (1997) 'Business Alliances, Network Construction and Agenda Definition:

Recent Development in Lobbying Activities in Brussels and Strasbourg', paper prepared for delivery at the Fifth Biennial International Conference of the European Community Studies Association, Seattle, 29 May to 1 June

Coen, D (1997) 'The evolution of the large firm as a political actor in the European Union', Journal of European Public Policy, 4: 1, March, pp 91-108

Coen, D (1998) The European Business Interest and the Nation State: Large-Firm Lobbying in the European Union and Member States, Journal of Public Policy, 18, 1, pp 75-100

Coleman, W and Grant, W (1988) 'The Organizational Cohesion and Political Access of Business: A Study of Comprehensive Associations’, European Journal of Political Research, 16: 467-87

Compass Partnership (1997) Trade Association Performance: Report of a benchmarking exercise of trade associations, London, ABI 
Euroconfidentiel (1998) World Directory of 9300 Trade and Professional Associations in the EU, Genval, Euroconfidentiel

Euroconfidentiel (1999) Directory of EU Information Sources, Genval, Euroconfidentiel

Euromonitor (1999) World Directory of Trade and Business Associations, London, Euromonitor

European Commission (1999) Directory of Interest Groups in the European Union, http://europa.eu.int/comm/secretariat_general/sgc/lobbies/repertoire/indexrep_en.htm

Green Cowles, M (1995) 'The European Round Table of Industrialists: The Strategic Player in European Affairs', in Greenwood, J (ed.) European Casebook on Business Alliances, Hemel Hempstead, Prentice Hall, pp 225-236

Greenwood, J (2000) "EU Interest Groups and their Members: when is membership a 'collective action problem", in Balme R, Chabanet D and Wright V (2000, spring) (eds.) Collective Action in Europe, Oxford, Oxford University Press

Greenwood, J (1995a) (ed.) European Casebook on Business Alliances, Hemel Hempstead, Prentice Hall Greenwood, J (1995b) The Pharmaceutical Industry: A European Business Alliance That Works, in Greenwood, J (ed.) European Casebook on Business Alliances, Hemel Hempstead, Prentice Hall pp 38-48

Greenwood, J and Aspinwall, M (1997) Collective Action in the European Union: interests and the new politics of associability, London, Routledge

Hollingsworth, J R and Lindberg, L N (1985) 'The governance of the American economy: the role of markets, class, hierarchies, and associative behaviour', in Streeck, W and Schmitter, P. C. (eds.) Private Interest Government, London, Sage, pp 221-254

Huemer G, Mesch M and Traxler F (1999) (eds.), The Role of Employer Associations and Labour Unions in EMU: Institutional Requirements for European Economic Policies, Ashgate, Aldershot

Landmarks Publications (1998) European Public Affairs Directory 1999, Brussels, Landmarks Publications

Lanzalaco, L (1992) 'Coping with Heterogeneity: Peak Associations of Business within and across Western European Nations', in Greenwood J, Grote J and Ronit K (eds.) Organized Interests and the European Community, London, Sage, pp 173-205

McCann, D (1995) Small States, Open Markets and the Organisation of Business Interests, Aldershot, Dartmouth

Olson, M (1965) The Logic of Collective Action, Cambridge (Mass.), Harvard University Press

Olson, M (1995) The Varieties of Eurosclerosis: The Rise and Decline of Nations since 1982, EUI/Robert Schuman Centre, Jean Monnet Chair Papers, Florence, European University Institute

Pedler, R and van Schendelen, M P C M (1994) Lobbying the European Union: Companies, Trade Associations and Issue Groups, Aldershot, Dartmouth

Redpath, S (1996) 'Stop the Rot', Association Executive, Summer 1996, p.15

Streeck, W and Schmitter, P C (1985) Private Interest Government, London, Sage

Streeck, W and Schmitter, P C (1991) 'From National Corporatism to Transnational Pluralism', Politics and Society, 19, 2, pp 133-65 
Traxler, F (1991) 'The Logic of Employers' Collective Action', in Sadowski, D and Jacobi, O (eds.) Employers' Associations in Europe: Policy and Organisation, pp 28-50

Union of International Associations (1998) Yearbook of International Organizations, Frankfurt, Bowker-Saur

van Waarden, F (1991) 'Two Logics of Collective Action? Business Associations as Distinct from Trade Unions: The Problems of Associations as Organisations', in Sadowski, D and Jacobi, O (eds.) Employers' Associations in Europe: Policy and Organisation, pp 51-84

White, D (1997) 'Dealing with trade associations: a two way process', in Bennett, R (ed.) Trade Associations in Britain and Germany, London, Anglo-German Foundation, pp 74-77

\section{Endnotes}

(*) The author is grateful to the two anonymous referees of the EIoP for their helpful comments.

(1) These sources include those from the European Commission, 1999; Euromonitor, 1999;

Euroconfidentiel 1998; 1999; Landmarks Publications, 1999; the Union of International Associations 1998; and Butt-Phillip and Gray, 1996.

(2) This is part of a comprehensive, three stage research project involving data collection with 50 EU business associations, 200 members and non members of such associations, and personnel throughout the EU institutions. The data collection is not yet complete, and, when it is, will be reported in Greenwood (2001). Consequently, this preliminary article attempts to provide 'rich insights', a 'flavour' of the data and the direction in which it points, rather than attempting to report on it systematically.

(3) European Federation of Pharmaceutical Industry Associations.

(4) European Federation of the Iron and Steel Industries. 